University of Nebraska - Lincoln

DigitalCommons@University of Nebraska - Lincoln

Prophylaxis with human serum butyrylcholinesterase protects guinea pigs exposed to multiple lethal doses of soman or VX

\author{
Ashima Saxena \\ Walter Reed Army Institute of Research, ashima.saxena@us.army.mil \\ Wei Sun \\ Walter Reed Army Institute of Research \\ James M. Fedorko \\ Walter Reed Army Institute of Research \\ Irwin Koplovitz \\ US Army Medical Research Institute of Chemical Defense \\ Bhupendra P. Doctor \\ US Army Medical Research Institute of Chemical Defense
}

Follow this and additional works at: https://digitalcommons.unl.edu/usarmyresearch

Part of the Operations Research, Systems Engineering and Industrial Engineering Commons

Saxena, Ashima; Sun, Wei; Fedorko, James M.; Koplovitz, Irwin; and Doctor, Bhupendra P., "Prophylaxis with human serum butyrylcholinesterase protects guinea pigs exposed to multiple lethal doses of soman or VX" (2011). US Army Research. 151.

https://digitalcommons.unl.edu/usarmyresearch/151

This Article is brought to you for free and open access by the U.S. Department of Defense at DigitalCommons@University of Nebraska - Lincoln. It has been accepted for inclusion in US Army Research by an authorized administrator of DigitalCommons@University of Nebraska - Lincoln. 


\title{
Prophylaxis with human serum butyrylcholinesterase protects guinea pigs exposed to multiple lethal doses of soman or $\mathrm{VX}^{\text {th }}$
}

\author{
Ashima Saxena ${ }^{\mathrm{a}, 1, *}$, Wei Sun ${ }^{\mathrm{a}, 1}$, James M. Fedorko ${ }^{\mathrm{a}}$, Irwin Koplovitz ${ }^{\mathrm{b}}$, Bhupendra P. Doctor ${ }^{\mathrm{a}}$ \\ a Division of Biochemistry, Walter Reed Army Institute of Research, Silver Spring, MD 20910, USA \\ ${ }^{\mathrm{b}}$ Drug Assessment Division, US Army Medical Research Institute of Chemical Defense, Aberdeen Proving Ground, MD 21010, USA
}

\section{A R T I C L E I N F O}

\section{Article history:}

Received 22 July 2010

Accepted 7 September 2010

\section{Keywords:}

Human serum butyrylcholinesterase

Soman

VX

Bioscavenger

Prophylaxis

Guinea pigs

\begin{abstract}
A B S T R A C T
Human serum butyrylcholinesterase ( $\mathrm{Hu} \mathrm{BChE}$ ) is currently under advanced development as a bioscavenger for the prophylaxis of organophosphorus (OP) nerve agent toxicity in humans. It is estimated that a dose of $200 \mathrm{mg}$ will be required to protect a human against $2 \times \mathrm{LD}_{50}$ of soman. To provide data for initiating an investigational new drug application for the use of this enzyme as a bioscavenger in humans, we purified enzyme from Cohn fraction IV-4 paste and initiated safety and efficacy evaluations in mice, guinea pigs, and non-human primates. In mice, we demonstrated that a single dose of enzyme that is 30 times the therapeutic dose circulated in blood for at least four days and did not cause any clinical pathology in these animals. In this study, we report the results of safety and efficacy evaluations conducted in guinea pigs. Various doses of Hu BChE delivered by i.m. injections peaked at $\sim 24 \mathrm{~h}$ and had a mean residence time of 78-103 h. Hu BChE did not exhibit any toxicity in guinea pigs as measured by general observation, serum chemistry, hematology, and gross and histological tissue changes. Efficacy evaluations showed that $\mathrm{Hu} \mathrm{BChE}$ protected guinea pigs from an exposure of $5.5 \times \mathrm{LD}_{50}$ of soman or $8 \times \mathrm{LD}_{50}$ of VX. These results provide convincing data for the development of $\mathrm{Hu} \mathrm{BChE}$ as a bioscavenger that can protect humans against all OP nerve agents.
\end{abstract}

Published by Elsevier Inc.

\section{Introduction}

Organophosphorus (OP) nerve agents such as soman (GD), sarin, VX, and tabun, exert toxicity by inhibiting acetylcholinesterase (AChE) in the peripheral and central nervous systems (CNS). The resultant increase in acetylcholine levels at cholinergic synapses produces an acute cholinergic crisis; if left untreated it can ultimately lead to death due to respiratory failure, caused by

\footnotetext{
is The opinions or assertions contained herein are the private views of the authors and are not to be construed as official or as reflecting the views of the Army or the Department of Defense.

Abbreviations: Hu BChE, human serum butyrylcholinesterase; AChE, acetylcholinesterase; OP, organophosphorus compounds; CNS, central nervous system; BTC, butyrylthiocholine iodide; DTNB, 5,5'-dithiobis (2-nitrobenzoic acid); DEPQ, 7(O,O-diethyl-phosphinyloxy)-1-methyl-quinolinium methylsulfate; MEPQ 7(methylethoxyphosphinyloxy)-1-methyl-quinolinium iodide; soman, $o$-pinacolyl methylphosphonofluoridate; VX, O-ethyl S-2-N,N-diisopropylaminoethyl methylphosphonothiolate; MRT, mean residence time; $C_{\max }$, maximal concentration; $T_{\max }$, time to reach the maximal concentration; $A U C \infty$, area under the plasma concentration time curve extrapolated to infinity.

* Corresponding author at: Division of Bacterial \& Rickettsial Diseases, Walter Reed Army Institute of Research, 503 Robert Grant Avenue, Silver Spring, MD 20910-7500, USA. Tel.: +1 301319 9406; fax: +1 3013199081.

E-mail address: ashima.saxena@us.army.mil (A. Saxena).

${ }^{1}$ Present address: Division of Bacterial \& Rickettsial Diseases, Walter Reed Army Institute of Research, Silver Spring, MD 20910, USA..
}

effects at central (loss of respiratory drive) and/or peripheral (weakness at diaphragm and intercostals muscles) systems [1]. Current medical countermeasures against OP nerve agent poisoning include a combination of pretreatment with a carbamate, pyridostigmine bromide, to protect a fraction of AChE from irreversible inhibition by OPs, followed by post-exposure treatment with anticholinergic drugs such as atropine sulfate to counteract the effects of excess acetylcholine, and oximes such as 2-PAM chloride, to reactivate OP-inhibited AChE. These antidotal regimens are effective in preventing lethality of animals from OP poisoning, but they do not prevent post-exposure incapacitation, convulsions, performance deficits or in many cases, permanent brain damage [2-4].

These problems stimulated the development of enzyme bioscavengers as prophylactic agents to neutralize highly toxic OP nerve agents before they reach their physiological targets [4]. Among the candidate enzymes examined, considerable progress was made using plasma-derived cholinesterases (ChEs). Exogenously administered AChE from fetal bovine serum and butyrylcholinesterase (BChE; EC 3.1.1.8) from equine and human (Hu) serum were successfully shown to prevent poisoning by OP compounds, in both rodent and non-human primate models [5]. Of these ChEs, Hu BChE is currently the most suitable enzyme for alleviating toxicity in humans exposed to OP compounds, including nerve agents and pesticides [6]. First, it reacts rapidly 
with highly toxic OPs, including soman, sarin, tabun, and VX. Second, it possesses a very long retention time in human circulation and is readily absorbed from sites of injection. Third, multiple administrations of $\mathrm{Hu} \mathrm{BChE}$ into humans are not expected to produce any adverse immunological responses since it is a soluble enzyme that is normally present in human circulation. Due to the large amount of $\mathrm{Hu} \mathrm{BChE}$ needed to neutralize the amount of OP pesticide typically ingested in a case of suicide, the use of $\mathrm{Hu}$ $\mathrm{BChE}$ as a stoichiometric bioscavenger is not practical. However, it was shown that inclusion of fresh frozen plasma (which contains significant amounts of $\mathrm{Hu} \mathrm{BChE}$ ) in the therapeutic regimen with atropine and/or pralidoxime increased its effectiveness in preventing morbidity and mortality in patients with OP pesticide poisoning [7]. In addition to preventing OP toxicity, exogenously administered $\mathrm{Hu}$ BChE was shown to be useful for alleviating succinylcholine-induced apnea [8]. Studies in animals have also demonstrated that the enzyme can be used for treating the toxic effects of cocaine [9-11]. Hu BChE is a stoichiometric bioscavenger in that $1 \mathrm{~mol}$ of enzyme binds to and neutralizes $1 \mathrm{~mol}$ of OP. A dose of $200 \mathrm{mg}(2.4 \mu \mathrm{mol})$ of $\mathrm{Hu} \mathrm{BChE}$ is envisioned as a prophylactic treatment in humans that can protect from exposure of up to $2 \times \mathrm{LD}_{50}$ of soman [12].

The foremost requirement to advance $\mathrm{Hu} \mathrm{BChE}$ as a bioscavenger for human use was to obtain sufficient amounts of purified enzyme to provide pre-clinical pharmacological information for conducting phase I clinical trials of $\mathrm{Hu} \mathrm{BChE}$ in humans. Toward this effort, we developed a procedure for the pilot-scale manufacture of Hu BChE from Cohn fraction IV-4 paste, which yielded 6-7 g (4.3-5 million $\mathrm{U}$ ) of purified enzyme from $80 \mathrm{~kg}$ of Cohn fraction IV-4 paste [13]. The enzyme was $>97 \%$ pure as judged by a specific activity of $\sim 700 \mathrm{U} / \mathrm{mg}$ and a major band on SDS-PAGE. However, prior to the first-dose-in-man studies, the safety of $\mathrm{Hu} B C h E$ had to be assessed in two animal models to identify or characterize any secondary unwanted pharmacological or toxicological effects, which could influence organ functions in humans. Furthermore, results of pharmacokinetic studies and in vitro stability of the enzyme will provide valuable guidelines for its dose design and storage shelf-life. Therefore, the pharmacokinetics as well as safety of purified $\mathrm{Hu} \mathrm{BChE}$ were first investigated in mice [14]. In mice administered with various doses of up to $90 \mathrm{mg} / \mathrm{kg}(1.08 \mu \mathrm{mol} / \mathrm{kg})$, enzyme activity reached peak levels in circulation at $10 \mathrm{~h}$ and $24 \mathrm{~h}$ following i.p. and i.m. injections, respectively. The enzyme displayed a mean residence time (MRT) of 40-50 h, regardless of the route of injection or dose of injected enzyme. Also, Hu BChE did not exhibit any systemic toxicity in mice as measured by general observation, serum chemistry, hematology, and gross and histological tissue changes. The behavioral safety of a large dose of Hu BChE was evaluated by Clark et al. [15] who exposed mice to $2000 \mathrm{U}$ ( $34.3 \mathrm{nmol}$ ) of $\mathrm{Hu} \mathrm{BChE}$ ( $\sim 30$ times the dose required for protecting humans from $2 \times \mathrm{LD}_{50}$ of soman) followed by an assessment of acoustic startle reactivity (ASR) and prepulse inhibition (PPI). They demonstrated that a 600-fold increase in BChE activity in circulation did not alter ASR or PPI behavior.

As a continuation of this effort, we examined the pharmacokinetics and safety of large doses of $\mathrm{Hu} \mathrm{BChE}$ in guinea pigs. Guinea pigs were administered 3-60 $\mathrm{mg} / \mathrm{kg}$ of $\mathrm{Hu} \mathrm{BChE}$ by i.m. injection and blood was sampled at various time intervals to characterize the pharmacokinetics of $\mathrm{Hu}$ BChE. The safety of $\mathrm{Hu}$ BChE was assessed by general observation, serum chemistry and hematology as well as gross and histological tissue analyses. The efficacy of the enzyme was also evaluated against at least $5 \times \mathrm{LD}_{50}$ of soman or VX. Results showed that $\mathrm{Hu}$ BChE delivered by i.m. injection displayed long-lasting circulatory stability and did not exhibit any toxicity in guinea pigs. All animals survived the $5.5 \times \mathrm{LD}_{50}$ soman challenge while most animals survived the $8 \times \mathrm{LD}_{50}$ VX challenge. These results provide convincing data for the development of $\mathrm{Hu}$
$\mathrm{BChE}$ as a bioscavenger that can protect humans against all OP nerve agents.

\section{Materials and methods}

All animal studies were conducted in compliance with the Animal Welfare Act and other federal statutes and regulations stated in the Guide for the Care and Use of Laboratory Animals (NRC Publication, 1996 edition). All procedures with animals received prior approval from Walter Reed Army Institute of Research (WRAIR)/Naval Medical Research Center (NMRC) or US Army Medical Research Institute of Chemical Defense (USAMRICD) Institutional Animal Care and Use Committee and were performed in facilities fully accredited by the Association for Assessment and Accreditation of Laboratory Animal Care, International.

\subsection{Materials}

All reagent grade chemicals including butyrylthiocholine (BTC), 5,5-dithiobisnitrobenzoic acid (DTNB), and procainamide hydrochloride were purchased from Sigma Chemical Co. (St. Louis, MO). $\mathrm{Hu}$ BChE was isolated from Cohn fraction IV-4 paste [13] and stored in lyophilized form at $-20^{\circ} \mathrm{C}$. Nerve agents soman and VX were obtained from the U.S. Army Edgewood Chemical and Biological Center, Aberdeen Proving Ground, MD. The purity of all nerve agents was $>98.5 \%$ as determined by ${ }^{31} \mathrm{P}$ NMR.

\subsection{Pharmacokinetics of $\mathrm{Hu} B C h E$ in guinea pigs}

These studies were conducted at WRAIR. Dunkin Hartley guinea pigs (Cavia porcellus) weighing 300-450 g were obtained from Charles River Laboratories (Kingston, NY). Guinea pigs ( $n=6$; equal number of males and females) were administered $\mathrm{Hu}$ BChE at doses of 3,30 , or $60 \mathrm{mg} / \mathrm{kg}(36,360$, or $720 \mathrm{nmol} / \mathrm{kg}$ ) by i.m. injection. Following enzyme administration, $10 \mu \mathrm{l}$ of blood was drawn from the ear vein at various time intervals and diluted 20 times with water for the determination of blood BChE activity [16]. The following pharmacokinetic parameters were determined from the time course curve of blood BChE concentration: MRT, maximal concentration $\left(C_{\max }\right)$, time to reach the maximal concentration $\left(T_{\max }\right)$, elimination half-life $\left(T_{1 / 2}\right)$, and area under the plasma concentration time curve extrapolated to infinity (AUC), using a Windows-based program for non-compartmental analysis of pharmacokinetic data [17].

\subsection{Safety of $\mathrm{Hu} B C h E$ in guinea pigs}

Guinea pigs ( $n=6$; equal number of males and females) were administered either saline or $\mathrm{Hu}$ BChE at a dose of $60 \mathrm{mg} / \mathrm{kg}$ $(720 \mathrm{nmol} / \mathrm{kg}$ ) by i.m. or i.p. injection. Following the administration of saline or Hu BChE, animals were observed for any abnormal physiological or behavioral signs for 14 days. The animals were euthanized and blood was collected for determining hematology and serum chemistry parameters. All parameter values were expressed as mean \pm S.E.M. Statistical evaluation of values was performed using an unpaired $t$-test (comparison of different groups) and $p$ values $\leq 0.05$ were taken as being statistically significant. Following blood collection, a complete necropsy was performed and a full set of tissues, including brain, heart, lung, liver, intestine, kidney, eye, spleen, and muscle injection sites, were examined for any gross or histological changes.

\subsection{Efficacy of $\mathrm{Hu} B C h E$ in guinea pigs}

These studies were conducted at USAMRICD. The efficacy of $\mathrm{Hu}$ $\mathrm{BChE}$ was evaluated in guinea pigs as described [18]. Male Dunkin 
Hartley guinea pigs $(n=10)$ were pretreated with sufficient quantity of $\mathrm{Hu} \mathrm{BChE}$ to neutralize an $8 \times \mathrm{LD}_{50}$ challenge of soman or VX, by i.m. injection. Blood samples were drawn via toe clip at 18-20 h post enzyme administration for the determination of BChE activity [16]. Within $15 \mathrm{~min}$, animals were challenged with $1.5 \times \mathrm{LD}_{50}$ of soman $\left(1 \times \mathrm{LD}_{50}=30 \mu \mathrm{g} / \mathrm{kg}(165 \mathrm{nmol} / \mathrm{kg})\right)$ by s.c. injection. All animals were observed for signs of intoxication for $90 \mathrm{~min}$, after which a second blood sample was taken for the determination of blood BChE activity. On the basis of circulating BChE activity, the animals were challenged with another $2 \times \mathrm{LD}_{50}$ of soman by s.c. injection. Again, the animals were observed for $90 \mathrm{~min}$, and if no signs of intoxication were observed, another blood sample was drawn for the determination of BChE activity and the animals were challenged with $2 \times \mathrm{LD}_{50}$ of soman one more time for a total challenge of $5.5 \times \mathrm{LD}_{50}$. Ninety minutes following the third challenge with soman, a final blood sample was taken for the analysis of BChE activity and the surviving animals were held for observation. One-half of the animals were randomly euthanized after 7 days and the remaining animals were euthanized 14 days post-nerve agent challenge, for the examination of tissues by light microscopy.

A similar paradigm was used for determining the efficacy of $\mathrm{Hu}$ BChE against $\mathrm{VX}\left(1 \times \mathrm{LD}_{50}=9 \mu \mathrm{g} / \mathrm{kg}(34 \mathrm{nmol} / \mathrm{kg})\right)$, except that the animals were sequentially challenged with $2.0,2.0$, and $1.0 \times \mathrm{LD}_{50}$ of VX by s.c. injection for a total challenge of $5.0 \times \mathrm{LD}_{50}$ on the first day. Twenty hours following the third challenge with VX, blood was drawn for the analysis of BChE activity. Animals were again challenged with $1.5 \times \mathrm{LD}_{50}$ of VX by s.c. injection. All animals were observed for signs of intoxication for $90 \mathrm{~min}$, after which a second blood sample was taken for the determination of blood BChE activity. On the basis of circulating BChE activity, the animals were challenged with another $1.5 \times \mathrm{LD}_{50}$ of VX by s.c. injection. Blood samples were taken at $24 \mathrm{~h}$ and $48 \mathrm{~h}$ following the last challenge with VX for the analysis of BChE activity. The surviving animals were euthanized 7 days post-nerve agent challenge and tissues were examined by light microscopy.

\section{Results}

\subsection{Pharmacokinetics and safety of $\mathrm{Hu} B C h E$ in guinea pigs}

Time courses of three doses of $\mathrm{Hu}$ BChE administered into guinea pigs by i.m. injection are shown in Fig. 1 and the calculated pharmacokinetic parameters are shown in Table 1. Guinea pigs

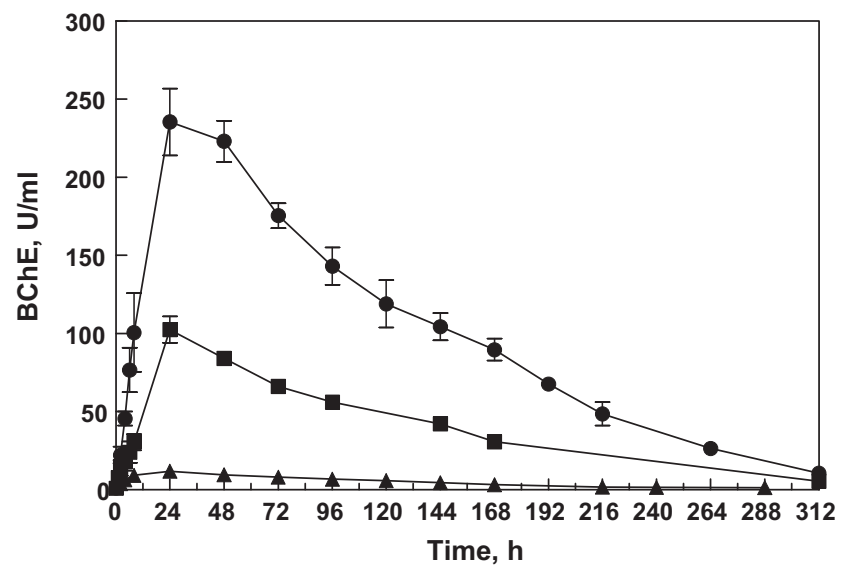

Fig. 1. Average enzyme activity in the blood of guinea pigs following injections of Hu BChE. Animals in each group $(n=6)$ were delivered $3 \mathrm{mg} / \mathrm{kg}(\boldsymbol{\Delta}), 30 \mathrm{mg} / \mathrm{kg}(\boldsymbol{\square})$, or $60 \mathrm{mg} / \mathrm{kg}$ ( ) of Hu BChE by i.m. injection. Animals injected with saline served as controls (data not shown). Following enzyme administration, $10 \mu \mathrm{l}$ of blood was drawn at various time intervals for the determination of blood BChE activity [16].
Table 1

Pharmacokinetic parameters of $\mathrm{Hu} \mathrm{BChE}$ in guinea pigs ${ }^{\mathrm{a}}$.

\begin{tabular}{lccc}
\hline Parameters & \multicolumn{3}{l}{ Dose $(\mathrm{mg} / \mathrm{kg})$} \\
\cline { 2 - 4 } & 3 & 30 & 60 \\
\hline$C_{\max }(\mathrm{U} / \mathrm{ml})$ & $10.3 \pm 0.3$ & $101.5 \pm 5.8$ & $257.9 \pm 12.4$ \\
MRT $(\mathrm{h})$ & $73 \pm 5$ & $98 \pm 6$ & $103 \pm 3$ \\
$\mathrm{AUC} \infty\left(\mathrm{Uh} \mathrm{ml} \mathrm{h}^{-1}\right)$ & $1050 \pm 20$ & $11,270 \pm 490$ & $34,200 \pm 2050$ \\
$T_{\max }(\mathrm{h})$ & 24 & 24 & 24 \\
\hline
\end{tabular}

${ }^{\mathrm{a}} \mathrm{Hu} \mathrm{BChE}$ was administered by i.m. injection.

that were administered 3,30 or $60 \mathrm{mg} / \mathrm{kg}$ of $\mathrm{Hu}$ BChE by i.m. injection showed a rapid increase in BChE activity, which reached peak levels at $\sim 24 \mathrm{~h}$. The enzyme was highly stable in circulation and displayed an MRT of 78-110 h.

The safety of Hu BChE was evaluated in guinea pigs that were administered $60 \mathrm{mg}(720 \mathrm{nmol}) / \mathrm{kg}$ of enzyme. Guinea pigs with circulating levels of BChE as high as $260 \mathrm{U}(4.46 \mathrm{nmol}) / \mathrm{ml}$ did not display any signs of clinical toxicity. All guinea pigs appeared in good health and gained an average body weight of $67 \pm 5 \mathrm{~g}$ (saline group), $67 \pm 10 \mathrm{~g}$ (Hu BChE, i.p. group) and $69 \pm 10 \mathrm{~g}$ (Hu BChE, i.m. group) during the experimental period. Animals were euthanized after two weeks post-Hu BChE injection and blood samples were examined for hematology (Table 2) and serum chemistry parameters (Table 3 ). All hematology and serum chemistry parameters measured were within the reported normal physiological ranges [19]. There were no significant clinical differences between saline and Hu BChE treated groups as indicated by $p$ values $>0.05$, except for RBC, HGB, HCT, MCHC and ALP, which showed $p$ values between 0.001 and 0.02 . The values for RBC, HGB, HCT, MCHC, and ALP were in the normal physiological ranges for all groups, suggesting that these differences are not biologically relevant. A complete necropsy was also performed and a full set of tissues, including brain, heart, lung, liver, intestine, kidney, eye, spleen, and muscle injection sites, were examined for any gross or histological changes. No lesions or other evidence of histopathology were observed in any subjects treated with $\mathrm{Hu}$ BChE. Results of necropsy together with hematology and serum chemistry parameters did not reveal any clinical signs of pathology in these animals that received a large dose of $\mathrm{Hu}$ BChE.

\subsection{Efficacy of $\mathrm{Hu} B C h E$ in guinea pigs}

The efficacy of Hu BChE was evaluated in guinea pigs against multiple $\mathrm{LD}_{50}$ challenges of soman or VX. Guinea pigs were

Table 2

Hematological profiles of guinea pigs following administration of $\mathrm{Hu} \mathrm{BChE}$.

\begin{tabular}{lccc}
\hline Parameters & Saline & $\begin{array}{l}\text { Hu BChE } \\
(60 \mathrm{mg} / \mathrm{kg}, \mathrm{i} . \mathrm{p} .)\end{array}$ & $\begin{array}{l}\text { Hu BChE } \\
(60 \mathrm{mg} / \mathrm{kg}, \mathrm{i} . \mathrm{m} .)\end{array}$ \\
\hline WBC $\left(\times 10^{3} / \mu \mathrm{l}\right)$ & $4.0 \pm 0.3$ & $4.5 \pm 0.5$ & $4.2 \pm 0.5$ \\
RBC $\left(\times 10^{6} / \mu \mathrm{l}\right)$ & $5.0 \pm 0.1$ & $5.5 \pm 0.1^{*}$ & $5.5 \pm 0.1^{*}$ \\
HGB $(\mathrm{g} / \mathrm{dl})$ & $14 \pm 0.3$ & $15 \pm 0.2^{*}$ & $15 \pm 0.4^{*}$ \\
HCT $(\%)$ & $41 \pm 0.8$ & $45 \pm 0.6^{*}$ & $46 \pm 1.4^{*}$ \\
MCV (fl) & $81 \pm 0.8$ & $82 \pm 0.4$ & $84 \pm 1.3$ \\
MCH (pg) & $28 \pm 0.4$ & $28 \pm 0.2$ & $28 \pm 0.5$ \\
MCHC $(\mathrm{g} / \mathrm{dl})$ & $34 \pm 0.1$ & $34 \pm 0.2$ & $33 \pm 0.1^{*}$ \\
RDW $(\%)$ & $9.2 \pm 0.1$ & $9.3 \pm 0.2$ & $9.1 \pm 0.2$ \\
PLT $\left(\times 10^{3} / \mu \mathrm{l}\right)$ & $294 \pm 55$ & $310 \pm 55$ & $217 \pm 26$ \\
MPV $(\mathrm{fl})$ & $7.8 \pm 0.3$ & $7.8 \pm 0.4$ & $7.9 \pm 0.2$ \\
PCT $(\%)$ & $0.22 \pm 0.04$ & $0.24 \pm 0.04$ & $0.17 \pm 0.02$ \\
PDW $(\%)$ & $12.1 \pm 0.9$ & $11.9 \pm 1.0$ & $12.6 \pm 0.5$ \\
\hline
\end{tabular}

Values are mean \pm S.E.M. WBC, white blood count; RBC, red blood cell count; HGB, hemoglobin; HCT, hematocrit; MCV, mean corpuscular volume; $\mathrm{MCH}$, mean corpuscular hemoglobin; MCHC, mean corpuscular hemoglobin concentration; RDW, red cell distribution width; PLT, platelet count; MPV, mean platelet volume; PCT, plateletcrit; PDW, platelet volume distribution width.

$p$ values $\leq 0.05$ between saline and $\mathrm{Hu}$ BChE treated groups. 
Table 3

Serum chemistry profiles of guinea pigs following administration of $\mathrm{Hu}$ BChE.

\begin{tabular}{|c|c|c|c|}
\hline Parameters & Saline & $\begin{array}{l}\text { Hu BChE } \\
\text { (60 mg/kg, i.p.) }\end{array}$ & $\begin{array}{l}\text { Hu BChE } \\
\text { (60 mg/kg, i.m.) }\end{array}$ \\
\hline \multicolumn{4}{|c|}{ Metabolism \& renal function } \\
\hline Calcium (mg/dl) & $10.1 \pm 0.4$ & $10.3 \pm 0.5$ & $10.0 \pm 0.6$ \\
\hline Carbon dioxide (mmol/l) & $24 \pm 1$ & $22 \pm 3$ & $23 \pm 3$ \\
\hline Chloride $(\mathrm{mmol} / \mathrm{l})$ & $103 \pm 1$ & $101 \pm 1$ & $106 \pm 3$ \\
\hline Creatinine (mg/dl) & $0.4 \pm 0.0$ & $0.4 \pm 0.0$ & $0.5 \pm 0.0$ \\
\hline Phosphorus (mg/dl) & $8.6 \pm 0.5$ & $7.8 \pm 1.1$ & $7.4 \pm 0.6$ \\
\hline Sodium $(\mathrm{mmol} / \mathrm{l})$ & $136 \pm 1$ & $134 \pm 1$ & $143 \pm 4$ \\
\hline Urea nitrogen (mg/dl) & $15.6 \pm 1$ & $15.0 \pm 1$ & $14.5 \pm 1$ \\
\hline \multicolumn{4}{|l|}{ Lipid profile } \\
\hline Triglycerides (mg/dl) & $102 \pm 22$ & $85 \pm 10$ & $80 \pm 19$ \\
\hline Cholesterol (mg/dl) & $53 \pm 4$ & $51 \pm 3$ & $52 \pm 8$ \\
\hline \multicolumn{4}{|l|}{ Liver function } \\
\hline Albumin $(\mathrm{g} / \mathrm{dl})$ & $1.9 \pm 0.1$ & $1.9 \pm 0.1$ & $2.1 \pm 0.2$ \\
\hline $\operatorname{ALP}(U / 1)$ & $104 \pm 6$ & $117 \pm 5$ & $132 \pm 4^{*}$ \\
\hline $\operatorname{ALT}(\mathrm{U} / \mathrm{l})$ & $86 \pm 23$ & $53 \pm 10$ & $48 \pm 3$ \\
\hline AST (U/1) & $275 \pm 92$ & $154 \pm 69$ & $99 \pm 28$ \\
\hline GGT (U/l) & $38 \pm 5$ & $61 \pm 9$ & $45 \pm 5$ \\
\hline $\mathrm{LDH}(\mathrm{U} / \mathrm{l})$ & $1187 \pm 272$ & $1292 \pm 115$ & $1068 \pm 53$ \\
\hline Total bili (mg/dl) & $0.5 \pm 0.1$ & $0.5 \pm 0.0$ & $0.5 \pm 0.1$ \\
\hline Total protein $(\mathrm{g} / \mathrm{dl})$ & $4.3 \pm 0.2$ & $4.5 \pm 0.1$ & $4.6 \pm 0.2$ \\
\hline \multicolumn{4}{|l|}{ Other } \\
\hline CK $(\mathrm{U} / \mathrm{l})$ & $311 \pm 24$ & $320 \pm 72$ & $403 \pm 77$ \\
\hline
\end{tabular}

Values are mean \pm S.E.M. ALP, alkaline phosphatase; ALT, alanine aminotransferase; AST, aspartate aminotransferase; BUN, blood urea nitrogen; CK, creatine kinase; GGT, gamma-glutamyl transpeptidase; LDH, lactate dehydrogenase.

$p$ value $\leq 0.05$ between saline and $\mathrm{Hu} \mathrm{BChE}$ treated group.

pretreated with an amount of $\mathrm{Hu}$ BChE that would protect them from an exposure to $8 \times \mathrm{LD}_{50}$ of agent and challenged with soman or VX, 18-20 h later. The sequential challenge design allowed us to conduct an in vivo titration of circulating $\mathrm{Hu} \mathrm{BChE}$ with the nerve agent used for challenge. As shown in Fig. 2, there was a decrease in molar concentration of circulating $\mathrm{Hu}$ BChE activity equivalent to the amount of soman administered at a given time period. For example, guinea pigs administered with $\mathrm{Hu} \mathrm{BChE}$ sufficient to provide protection against $8 \times \mathrm{LD}_{50}$ of soman attained peak blood BChE levels of approximately $300 \mathrm{U}(5.14 \mathrm{nmol}) / \mathrm{ml}$ and the enzyme level was reduced to approximately $100 \mathrm{U}(1.7 \mathrm{nmol}) /$ $\mathrm{ml}$ following challenge with $5.5 \times \mathrm{LD}_{50}$ of soman. This decrease of $\sim 200 \mathrm{U}(3.4 \mathrm{nmol}) / \mathrm{ml}$ in blood BChE level corresponds to the amount of enzyme required to neutralize $\sim 5.0-5.5 \times L_{50}$ of soman. No signs of OP poisoning were observed in animals that were pretreated with $\mathrm{Hu} \mathrm{BChE}$ and all animals survived the

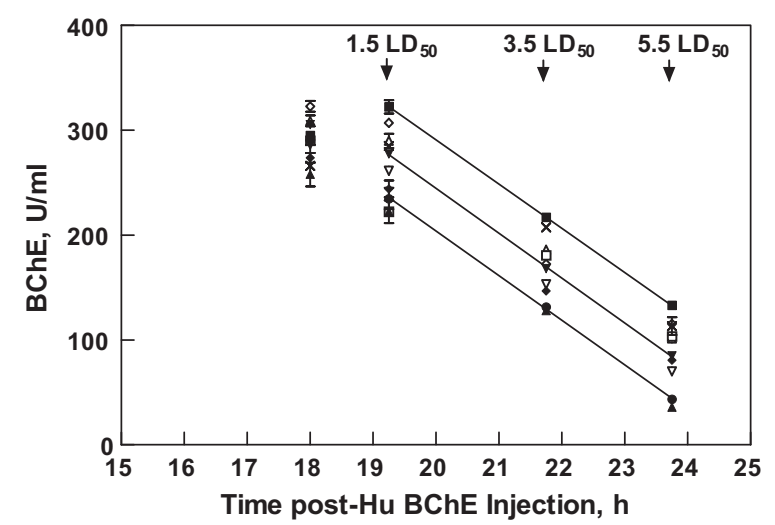

Fig. 2. In vivo titration of blood-BChE activity in guinea pigs pretreated with $\mathrm{Hu} B C h E$ and challenged with soman. Guinea pigs were pretreated with Hu BChE by i.m. injection and titrations were initiated after $18 \mathrm{~h}$, in accordance with the time profiles of blood BChE activity shown in Fig. 1. Consecutive s.c. challenges with 1.5, 2.0, and $2.0 \times \mathrm{LD}_{50}$ of soman were administered at $90 \mathrm{~min}$ intervals for a total challenge of $5.5 \times \mathrm{LD}_{50}$. Blood BChE activity assayed prior to each challenge is shown.

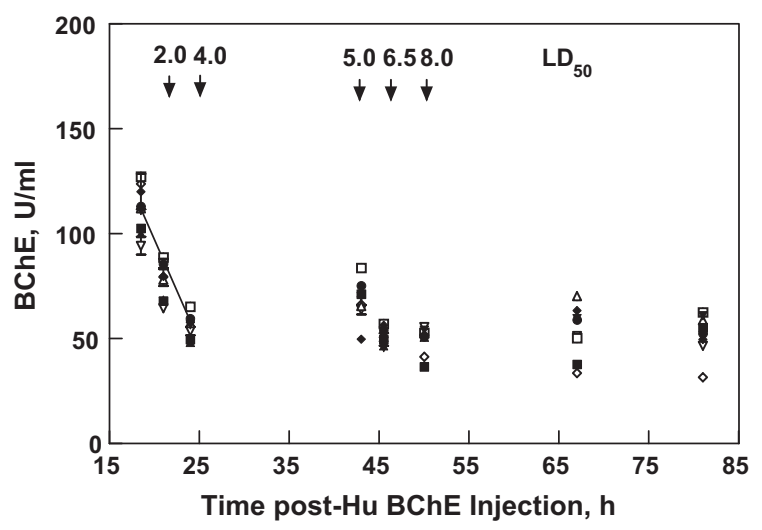

Fig. 3. In vivo titration of blood-BChE activity in guinea pigs pretreated with $\mathrm{Hu}$ $\mathrm{BChE}$ and challenged with VX. Guinea pigs were pretreated with $\mathrm{Hu}$ BChE by i.m. injection and titrations were initiated after $19 \mathrm{~h}$. Consecutive s.c. challenges with 2.0, 2.0, and $1.0 \times \mathrm{LD}_{50}$ of VX were administered at $90 \mathrm{~min}$ intervals for a total challenge of $5.0 \times \mathrm{LD}_{50}$ on the first day. Twenty hours following the third challenge with VX, blood was drawn for the analysis of BChE activity and the animals were sequentially challenged with $1.5 \times \mathrm{LD}_{50}$ of VX twice for an additional challenge of $3 \times \mathrm{LD}_{50}$. The cumulative challenge over a $24 \mathrm{~h}$ period was $8 \times \mathrm{LD}_{50}$. Blood $\mathrm{BChE}$ activity assayed prior to each challenge is shown.

duration of challenge. Animals were subjected to necropsy 7 or 14 days following nerve agent challenge and all tissues appeared normal upon light microscopic examination.

With VX challenge, less enzyme was administered since the $\mathrm{LD}_{50}$ of $\mathrm{VX}$ is lower than that for soman. The animals were sequentially challenged with $2.0,2.0$, and $1.0 \times \mathrm{LD}_{50}$ of $\mathrm{VX}$ for a total challenge of $5 \times \mathrm{LD}_{50}$, at $\sim 19 \mathrm{~h}$ post-administration of $\mathrm{Hu}$ BChE. Six of 9 animals showed transient mild symptoms such as abnormal chewing. The animals appeared healthy next morning, and were sequentially challenged with $1.5 \times \mathrm{LD}_{50}$ of VX twice for a total challenge of $3 \times \mathrm{LD}_{50}$. No signs of $\mathrm{OP}$ poisoning were observed after the first $1.5 \times \mathrm{LD}_{50}$ challenge; two animals showed local tremors, lacrimation, salivation, and crossed limbs following the second $1.5 \times \mathrm{LD}_{50}$ challenge. One animal was euthanized due to excessive weight loss; results of necropsy revealed a small gastric lesion, but all other tissues appeared normal upon light microscopic examination. Eight animals survived the $8 \times \mathrm{LD}_{50}$ challenge of VX; animals were subjected to necropsy and all tissues appeared normal upon light microscopic examination in seven animals. Neuronal necrosis was observed in the hippocampus of the animal that showed cholinergic symptoms following the last VX challenge.

The decrease in circulating BChE activity following each challenge is shown in Fig. 3. Guinea pigs administered with $\mathrm{Hu}$ $\mathrm{BChE}$ that was sufficient to provide protection against $8 \times \mathrm{LD}_{50}$ of VX attained peak blood BChE levels of approximately $110 \mathrm{U}$ $(1.9 \mathrm{nmol}) / \mathrm{ml}$ and enzyme activity was reduced to approximately $50 \mathrm{U}(0.86 \mathrm{nmol}) / \mathrm{ml}$ following challenge with $4.0 \times \mathrm{LD}_{50}$ of $\mathrm{VX}$. The animals were observed overnight following the third VX challenge, which also resulted in a redistribution of enzyme activity from tissues into circulation. The activity of $\sim 70 \mathrm{U}(1.2 \mathrm{nmol}) / \mathrm{ml}$ was reduced to $\sim 36 \mathrm{U}(0.62 \mathrm{nmol}) / \mathrm{ml}$ following the last VX challenge and was $\sim 25 \mathrm{U}(0.43 \mathrm{nmol}) / \mathrm{ml}$ when the animals were euthanized.

\section{Discussion}

$\mathrm{Hu} \mathrm{BChE}$ is currently under advanced development as a bioscavenger for the prophylaxis of OP nerve agent toxicity in humans. It is estimated that a dose of $200 \mathrm{mg}(2400 \mathrm{nmol})$ will be required to protect a human against $2 \times \mathrm{LD}_{50}$ of soman [12]. To advance $\mathrm{Hu} \mathrm{BChE}$ as a bioscavenger for human use, we isolated 6$7 \mathrm{~g}$ (4.3-5 million $\mathrm{U})$ of highly purified enzyme from $80 \mathrm{~kg}$ of Cohn 
fraction IV-4 paste [13]. To demonstrate that $\mathrm{Hu}$ BChE purified according to our procedure could function as a bioscavenger in animals and humans, we evaluated its circulatory stability, safety, and efficacy in two animal models. Results of pharmacokinetic studies as well as physiological and behavioral safety evaluations in mice demonstrated that $\mathrm{Hu} \mathrm{BChE}$ displayed long-lasting stability in circulation and was not toxic to animals $[14,15]$. As a continuation of this effort, here we extended the pharmacokinetic and safety evaluations in guinea pigs. In addition, we demonstrated for the first time the efficacy of Hu BChE against $5.5 \times \mathrm{LD}_{50}$ of soman and $8 \times \mathrm{LD}_{50}$ of $\mathrm{VX}$.

Indeed, doses of $3-60 \mathrm{mg}(36-720 \mathrm{nmol}) / \mathrm{kg}$ of $\mathrm{Hu} \mathrm{BChE}$ administered into guinea pigs by i.m. injection displayed a pharmacokinetic profile similar to that observed previously in rats and mice [14,20], guinea pigs [18,21], and rhesus monkeys $[22,23]$. The prolonged circulatory stability of the enzyme observed in guinea pigs (MRT $=78-110 \mathrm{~h}$ ) is consistent with that observed in mice $($ MRT $=48 \mathrm{~h}$ ) and monkeys (MRT $=72-74 \mathrm{~h}$ ) [24]. A dose of $60 \mathrm{mg}(720 \mathrm{nmol}) / \mathrm{kg}$ of $\mathrm{Hu} \mathrm{BChE}$ is sufficient for protecting guinea pigs from an exposure to $5 \times \mathrm{LD}_{50}$ of soman and is 20 times the human dose of $3 \mathrm{mg}$ ( $36 \mathrm{nmol}) / \mathrm{kg}$, which is predicted to provide protection from $2 \times \mathrm{LD}_{50}$ of soman [12]. All guinea pigs with circulating activity of $\mathrm{BChE}$ as high as $260 \mathrm{U}(4.46 \mathrm{nmol}) / \mathrm{ml}$ displayed no signs of clinical toxicity or pathology. These results are consistent with those reported in mice [14]. In addition, $\mathrm{Hu}$ BChE did not display any effects on behavioral tasks in mice as well as monkeys $[15,23]$. Taken together, these results suggest that $\mathrm{Hu}$ $\mathrm{BChE}$ is devoid of any significant systemic or behavioral toxicity.

Due to the limited availability of purified $\mathrm{Hu} \mathrm{BChE}$, most previous studies examined the efficacy of $\mathrm{Hu} \mathrm{BChE}$ against 2$3 \times \mathrm{LD}_{50}$ of OP nerve agents $[22,25,26]$. In this study, the efficacy of $\mathrm{Hu} \mathrm{BChE}$ was evaluated in guinea pigs against multiple $\mathrm{LD}_{50}$ challenges of soman or VX using a sequential challenge design, which allowed us to conduct an in vivo titration of circulating $\mathrm{Hu}$ $\mathrm{BChE}$ with the nerve agent used for challenge. In each case, the dose of enzyme administered was sufficient to neutralize $8 \times \mathrm{LD}_{50}$ of agent and the decrease in blood BChE activity following each challenge corresponds to the amount of enzyme required to neutralize the dose of OP nerve agent. A total challenge with $5.5 \times \mathrm{LD}_{50}$ of soman neutralized two-thirds of circulating $\mathrm{Hu} \mathrm{BChE}$ activity and the remaining activity was sufficient to neutralize an additional $2.5 \times \mathrm{LD}_{50}$ of soman. The stoichiometric protection by the enzyme was demonstrated in the study with VX in which the animals were challenged five times over a period of $24 \mathrm{~h}$, for a total challenge of $8 \times \mathrm{LD}_{50}$. Previously, Raveh et al., had reported that fetal bovine serum AChE protected mice against $8 \times \mathrm{LD}_{50}$ of 7 (methylethoxyphosphinyloxy)-1-methyl-quinolinium iodide (MEPQ), an analog of VX [27]. This is the first study demonstrating the ability of Hu BChE to protect from an exposure of $8 \times \mathrm{LD}_{50}$ of VX. Although pretreatment with $\mathrm{Hu}$ BChE provided symptom-free protection to all 10 animals challenged with soman, 8 of 10 animals challenged with $8 \times \mathrm{LD}_{50}$ of VX were protected. Also, animals displayed mild transient cholinergic symptoms, such as chewing, when the VX challenge exceeded $4 \times \mathrm{LD}_{50}$. This could be due to two reasons: (1) the rate of inhibition of $\mathrm{Hu} \mathrm{BChE}$ by $\mathrm{VX}$ is $4-5$-fold slower as compared to AChE [20], which would result in some inhibition of peripheral AChE by VX before it was neutralized by $\mathrm{Hu}$ $\mathrm{BChE}$; (2) the degradation of VX in vivo is slower as compared to Gagents $[28,29]$, which would prolong its time in circulation and increase its chance of inhibiting peripheral AChE. Despite these limitations, as shown in Fig. 3, Hu BChE was able to neutralize high doses of VX in circulation. These results clearly demonstrate that $\mathrm{Hu} \mathrm{BChE}$ can function as an effective stoichiometric bioscavenger for high doses of both G- and V-type of nerve agents. This is also supported by results of light microscopic examination of all tissues following nerve agent challenge. Taken together, these results provide convincing data for the development of $\mathrm{Hu} \mathrm{BChE}$ as a bioscavenger that can protect humans against all OP nerve agents.

\section{Conflict of interest statement}

The authors declare that there are no conflicts of interest.

\section{Acknowledgement}

The authors thank LTC Keith E. Steele for pathology services.

\section{References}

[1] McDonough JH, Shih T-M. Atropine and other anticholinergic drugs. In: Marrs TC, Maynard RL, Sidell FR, editors. Chemical warfare agents: toxicology and treatment. West Sussex, England: John Wiley \& Sons Ltd.; 2007.

[2] Dirnhuber P, French MC, Green DM, Leadbeater L, Stratton JA. The protection of primates against soman poisoning by pretreatment with pyridostigmine. J Pharm Pharmacol 1979;31:295-9.

[3] McLeod CGJ. Pathology of nerve agents: perspectives on medical management. Fundam Appl Toxicol 1985;5:S10-6.

[4] Dunn MA, Sidell FR. Progress in medical defense against nerve agents. JAMA 1989;262:649-52.

[5] Doctor BP, Maxwell DM, Ashani Y, Saxena A, Gordon RK. New approaches to medical protection against chemical warfare nerve agents. In: Somani SM, Romano Jr JA, editors. Chemical warfare nerve agents: toxicity at low levels. Washington, DC: CRC Press; 2001. p. 191-214.

[6] Ashani Y. Prospective of human butyrylcholinesterase as a detoxifying antidote and potential regulator of controlled-release drugs. Drug Dev Res 2000;50:298-308.

[7] Guven M, Sungur M, Eser B, Sari I, Altuntas F. The effects of fresh frozen plasma on cholinesterase levels and outcomes in patients with organophosphate poisoning. J Toxicol 2004;42:617-23.

[8] Stovner J, Stadskleiv K. Suxamethonium apnoea terminated with commercial serumcholinesterase. Acta Anaesth Scand 1976;20:211-5.

[9] Hoffman RS, Morasco R, Goldfrank LR. Administration of purified human plasma cholinesterase protects against cocaine toxicity in mice. J Toxicol 1996;34:259-66.

[10] Carmona GN, Schindler CW, Shoaib M, Jufer R, Cone EJ, Goldberg SR, et al. Attenuation of cocaine-induced locomotor activity by butyrylcholinesterase. Exp Clin Psychopharmacol 1998;6:274-9.

[11] Duysen EG, Bartels CF, Lockridge O. Wild-type and A328W mutant human butyrylcholinesterase tetramers expressed in Chinese hamster ovary cells have a 16-hour half-life in the circulation and protect mice from cocaine toxicity. J Pharmacol Exp Ther 2002;302:751-8.

[12] Ashani Y, Pistinner S. Estimation of the upper limit of human butyrylcholinesterase dose required for protection against organophosphates toxicity: mathematically based toxicokinetic model. Toxicol Sci 2004;77:358-67.

[13] Saxena A, Tipparaju P, Luo C, Doctor BP. Pilot-scale production of human serum butyrylcholinesterase suitable for use as a bioscavenger against nerve agent toxicity. Process Biochem 2010;45:1313-8.

[14] Saxena A, Sun W, Luo C, Doctor BP. Human serum butyrylcholinesterase: in vitro and in vivo stability, pharmacokinetics, and safety in mice. Chem-Biol Interact 2005;157-158:199-203.

[15] Clark MG, Sun W, Myers TM, Bansal R, Doctor BP, Saxena A. Effects of physostigmine and human butyrylcholinesterase on acoustic startle reflex and prepulse inhibition in C57BL/6J mice. Pharmacol Biochem Behav 2005;81:497-505.

[16] Ellman GL, Courtney KD, Andres Jr V, Feather-Stone RM. A new and rapid colorimetric determination of acetylcholinesterase activity. Biochem Pharmacol 1961; 7:88-95.

[17] Laub PB, Gallo JM. NCOMP-a Windows-based computer program for noncompartmental analysis of pharmacokinetic data. J Pharm Sci 1996; 85:393-5.

[18] Lenz DE, Maxwell DM, Koplovitz I, Clark CR, Capacio BR, Cerasoli DM, et al. Protection against soman or VX poisoning by human butyrylcholinesterase in guinea pigs and cynomolgus monkeys. Chem-Biol Interact 2005;157158:205-10.

[19] Waner T, Avidar Y, Peh H-C, Zass R, Bogin E. Hematology and clinical chemistry values of normal and euthymic hairless adult male Dunkin-Hartley guinea pigs (Cavia porcellus). Vet Clin Pathol 1996;25:61-4.

[20] Raveh L, Grunwald J, Marcus D, Papier Y, Cohen E, Ashani Y. Human butyrylcholinesterase as a general prophylactic antidote for nerve agent toxicity. In vitro and in vivo quantitative characterization. Biochem Pharmacol 1993:45:2465-74.

[21] Allon N, Raveh L, Gilat E, Cohen E, Grunwald J, Ashani Y. Prophylaxis against soman inhalation toxicity in guinea pigs by pretreatment alone with human serum butyrylcholinesterase. Toxicol Sci 1998;43:121-8.

[22] Raveh L, Grauer E, Grunwald J, Cohen E, Ashani Y. The stoichiometry of protection against soman and VX toxicity in monkeys pretreated with human butyrylcholinesterase. Toxicol Appl Pharmacol 1997;145:43-53. 
[23] Myers TM, Sun W, Bansal R, Clark MG, Saxena A, Doctor BP. Safety evaluation of human serum butyrylcholinesterase in rhesus monkeys. In: Proc joint service scientific conf on chem and biol def res; 2003.

[24] Doctor BP, Saxena A. Bioscavengers for the protection of humans against organophosphate toxicity. Chem-Biol Interact 2005;157-158: 167-71.

[25] Ashani Y, Shapira S, Levy D, Wolfe AD, Doctor BP, Raveh L. Butyrylcholinesterase and acetylcholinesterase prophylaxis against soman poisoning in mice. Biochem Pharmacol 1991;41:37-41.

[26] Brandeis R, Raveh L, Grunwald J, Cohen E, Ashani Y. Prevention of somaninduced cognitive deficits by pretreatment with human butyrylcholinesterase in rats. Pharmacol Biochem Behav 1993;46:889-96.
[27] Raveh L, Ashani Y, Levy D, De La Hoz D, Wolfe AD, Doctor BP. Acetylcholinesterase prophylaxis against organophosphate poisoning. Quantitative correlation between protection and blood-enzyme level in mice. Biochem Pharmacol 1989;38:529-34.

[28] Benschop HP, Trap HC, Spruit HE, Van Der Wiel HJ, Langenberg JP, De Jong LP. Low level nose-only exposure to the nerve agent soman: toxicokinetics of soman stereoisomers and cholinesterase inhibition in atropinized guinea pigs. Toxicol Appl Pharmacol 1998;153:179-85.

[29] van der Schans MJ, Lander BJ, van der Wiel H, Langenberg JP, Benschop HP. Toxicokinetics of the nerve agent (+/-)-VX in anesthetized and atropinized hairless guinea pigs and marmosets after intravenous and percutaneous administration. Toxicol Appl Pharmacol 2003;191:48-62. 